\title{
TRABALHO ANÁLOGO AO DE ESCRAVO NO BRASIL: NECESSIDADE DE EFETIVAÇÃO DAS POLÍTICAS PÚBLICAS DE VALORIZAÇÃO DO TRABALHO HUMANO
}

\author{
THE SLAVE ANALOGOUS WORK IN BRAZIL: THE \\ PUBLIC POLICIES OF VALUING THE HUMAN \\ WORK EFFECTIVENESS NEED
}

\author{
Cíntia Clementino Miranda ${ }^{1}$ \\ Lourival José de Oliveira ${ }^{2}$
}

\begin{abstract}
RESUMO:O presente estudo teve como objetivo estabelecer os parâmetros para caracterizar o trabalho análogo ao de escravo no Brasil. Procurou-se localizar os principais fatores que contribuem para a geração e manutenção desta forma criminosa de trabalho no Brasil. Ao mesmo tempo, foi demonstrada a fragilidade do Estado no seu combate. Por último, apresentou-se sugestões de ordem preventiva e repressiva para o enfrentamento deste problema, inclusive no tocante ao implemento de novas políticas públicas que levem em conta a integração de várias ações na área educacional, voltadas principalmente à qualificação da mão-de-obra, aperfeiçoamento dos procedimentos fiscalizatórios, para que seja efetivamente combatido o trabalho análogo ao de escravo, com a integração da iniciativa privada, de maneira a compor condutas múltiplas para a efetivação do princípio da valorização do trabalho humano.
\end{abstract}

Palavras Chave: Dignidade da pessoa humana; Trabalho escravo; Proteção ao trabalho.

\begin{abstract}
The current study aimed to establish parameters to characterize the analogous work of the slave in Brazil. I have tried to find and main factors which contributed to the generation and maintenance of this criminal way of the work in Brazil. At the same time, the fragility of the State has been shown to fight it. At last, I have presented suggestions of preventive an repressive nature to face this problem, including the implementation of new public policies that take into account the integration of several actions, referring in the educational area, the hand labor qualification, inspecting procedures that effectively fights the slave analogous work and the private sector initiative in these actions in a way that it creates an integrated whole for the human work valuing principle effectiveness.
\end{abstract}

Keywords: Human being dignity; Slave work; Work protection

\footnotetext{
$\overline{{ }^{1} \text { Acadêmica do } 5^{\circ}}$ ano de Direito da Universidade Estadual de Londrina.

${ }^{2}$ Doutor em Direito do Trabalho pela PUC-SP, Professor de Direito do Trabalho na Graduação do Curso de Direito da Universidade Estadual de Londrina e do Programa de Mestrado em Direito da Universidade Estadual de Londrina.
} 


\section{INTRODUÇÃO}

O presente trabalho, a partir de uma ótica constitucional, tem seu início com a discussão sobre a dignidade da pessoa humana e o que ela representa na vida de cada cidadão. $\mathrm{O}$ trabalho humano passou por muitas transformações em vários momentos da história mundial. No Brasil, a partir da promulgação da Constituição Federal de 1988, há uma valorização do trabalho, assim como conquista status de direito e garantia fundamental em um Estado Democrático de Direito. Em um segundo momento, ao mesmo tempo em que o trabalho é valorizado, surgem vários problemas, alguns deles recorrentes, como o trabalho análogo ao de escravo, tema central deste trabalho. Foi realizado um levantamento histórico sobre o tema proposto, no sentido de apresentar uma explicação para essa forma de degradação do trabalho no Brasil, que ofende diretamente os princípios constitucionais voltados à dignidade da pessoa humana.

Por sua vez, a Organização Internacional do Trabalho (OIT), criada em 1919, após o término da primeira guerra mundial, tem papel imprescindível no combate análogo ao de escravo, não apenas no Brasil, mas em todo o mundo. Vários exemplos de desrespeito ao trabalho humano são apresentados, exemplos de origem não apenas das regiões norte e nordeste, mas também a região sul é alvo desse crime.

A participação de algumas entidades é imprescindível no combate a este crime, tais como: Sindicatos, Ministério do Trabalho e Emprego e Ministério Público do Trabalho. Ao final do trabalho são feitas propostas interdisciplinares, com ações conjuntas a partir da construção de uma proposta educacional de qualidade. É também apresentada a análise da Proposta de Emenda Constitucional PEC n ${ }^{\circ} 438 / 2001$, que de certa forma busca o aperfeiçoamento das ações de combate ao trabalho análogo ao de escravo.

Juntamente com ações citadas, são debatidas as políticas que podem contribuir para combater o trabalho análogo ao de escravo, assim como algumas propostas simples que podem dar efetividade ao Plano de Erradicação do Trabalho Escravo, desenvolvido pelo Governo Federal.

Na elaboração do presente trabalho utilizou-se de pesquisas bibliográficas, jurisprudências e consultas à internet, haja vista o grande volume de material disponível para o assunto em tela. 


\title{
A DIGNIDADE DO TRABALHO HUMANO
}

Vários conceitos surgiram no decorrer dos séculos, principalmente após a Declaração dos Direitos do Homem e do Cidadão, em 1789, sobre dignidade no trabalho.

Um ponto ainda muito negativo com relação ao Brasil é justamente o total desrespeito à dignidade humana, ou seja, o trabalho análogo ao de escravo, apesar de a Convenção Americana de Direitos Humanos, combinada com o Pacto Internacional de Direitos Civis e Políticos, estabelecer que ninguém poderá ser submetido à escravidão. (FUNDAÇÃO INSTITUTO DE DIREITOS HUMANOS, 1969).

Kant (1980, p. 139) conceitua a dignidade da pessoa humana como um fim e não como meio, ele volta-se contra a coisificação do ser humano. Quando Kant posiciona-se no sentido de que o ser humano deve ser reconhecido como sujeito, tratado como fim em si mesmo, vislumbra-se não somente a dimensão individual da pessoa, mas também sua dimensão comunitária e social.

Em 15 de maio de 1891, deu-se um fato muito importante para a humanidade: a divulgação da Encíclica Rerum Novarum. (LEÃO XIII, 2010).Tal encíclica foi elaborada a partir do momento em que a Igreja Católica começou a se preocupar com a questão social apresentada na época, uma realidade que foi conseqüência da $1^{\text {a }}$ Revolução Industrial, sendo a miséria e a exploração dos operários um fato marcante. Há uma clara evidência do comprometimento da igreja com os interesses políticos e econômicos da época.

A intervenção do Estado na economia também pode ser explicado como uma necessidade de conter o avanço das ideias de "esquerda", engrandecidas com os acontecimentos na agrária Rússia de 1917.

Barbosa (2010) critica a posição da igreja católica:

\begin{abstract}
A preocupação imediata da Igreja não foi com a situação do operário em si, como ser humano despido de direitos básicos, submetido a um regime que chegou a ser pior do que a escravidão (os escravos, assim com os animais, não eram submetidos a longas jornadas de trabalho, pois representavam bens, e, como tais, deveriam ser usados com moderação, para não depreciarem-se; os operários europeus eram submetidos a uma jornada que chegava a dezesseis horas por dia.
\end{abstract}

Em 1931 foi publicada a Encíclica Quadragesimo Anno, elaborada pelo Papa Pio XI, constituindo-se, na verdade, como uma reedição da encíclica Rerum Novarum. Uma das ideias era ser vantajoso suavizar o contrato de trabalho com elementos extraídos da sociedade, de 
modo que operários se tornassem participantes na propriedade, ou na gestão, ou, em certas medidas, nos lucros obtidos.

Já na democracia, o princípio da dignidade deve ser supremo, ou seja, ele não admite confrontos ou sacrifícios em nome da segurança. O Brasil escolheu, a partir da promulgação da CF de 1988, viver em um Estado Democrático de Direito e garantir a efetividade dos direitos e garantias constitucionais. Sendo assim, o princípio da Dignidade Humana, juntamente com o da Vida, deve ser o centro de todos os outros princípios.

\section{O TRABALHO HUMANO ENQUANTO DIREITO FUNDAMENTAL}

O trabalho subordinado começou a ser "protegido", efetivamente, a partir do século XIX, como conseqüência, tanto de conquistas históricas quanto da organização de Estados em moldes liberais. No entanto, a busca da dignidade do trabalho humano, assim como seu reconhecimento, mostra-se muito mais remota.

Gomes (2005, p. 76), relata que a partir do século XVIII eclode o capitalismo, tendo a Inglaterra seu grande expoente. A indústria têxtil se desenvolveu e surgiram as primeiras máquinas de fiar. A máquina a vapor passou a fornecer energia à nova indústria. Uma nova realidade despontou.

Em que pese a importância dessas invenções formidáveis, pequenas empresas sucumbiram ou foram absorvidas pelas grandes indústrias, contribuindo, assim, para a miséria, tanto moral, quanto material da classe trabalhadora.

Empregado e empregador foram postos lado a lado, em uma falaciosa situação de igualdade formal. O que realmente aconteceu foi que os empregados foram obrigados, empurrados pela necessidade de sobrevivência, a se sujeitarem a todo tipo de exploração, escapando assim do desemprego e de sua maior concorrente: a máquina.

Para Engels, que por lá passa por volta de 1840, no relato de Bresciani (1987, p. 23), a multidão das ruas londrinas:

\footnotetext{
Tem em si qualquer coisa de repugnante que revolta a natureza humana. Fica assustado e indignado por ver centenas de milhares de pessoas se comprimindo e se acotovelando, parecendo nada ter em comum. A indiferença brutal e o isolamento insensível de cada um voltado para os seus interesses impedem até um olhar de relance para o outro. A desagregação da humanidade em mônadas, no qual cada um possui um princípio e uma finalidade de vida particulares, esta atomização do mundo, foi aqui levada ao extremo. Resulta disso que a guerra social, a guerra de todos contra todos, aqui, está abertamente declarada.
} 
Observa-se, a seguir, Marx (1998, p. 29) invocando a destruição da propriedade como meio de produção:

O proletariado utilizará o seu domínio político para ir arrancando todo o capital das mãos da burguesia, para centralizar todos os instrumentos de produção nas mãos do Estado, isto é, do proletariado organizado como classe dominante, e para aumentar o mais rápido possível a massa das forças produtivas. Naturalmente que isto, a princípio, só pode ser realizado mediante intervenções despóticas no direito de propriedade e nas relações de produção burguesas, por meio de medidas que economicamente parecem insuficientes e insustentáveis, mas que, no decurso do movimento ultrapassarão a si mesmas e são indispensáveis como meios para revolucionar todo o modo de produção.

Um marco importante na vida dos trabalhadores foi, sem dúvida, o Tratado de Versalhes (28 de junho de 1919), que instituiu a Organização Internacional do Trabalho (OIT). Em 1948 foi proclamada, pela Assembleia Geral da Organização das Nações Unidas, a Declaração Universal dos Direitos Humanos, a qual propaga no art. $1^{\mathrm{o}}$ que: "Todos os homens nascem livres e iguais em dignidade e direitos. São dotados de razão e consciência e devem agir em relação uns aos outros com espírito de fraternidade".

Os direitos sociais, culturais e econômicos receberam status constitucional apenas a partir do século XX, inicialmente com a Constituição mexicana, em 1917. Em seguida pela Constituição russa, em 1918 e finalmente pela Constituição alemã, em 1919.

\section{A DIGNIDADE NO TRABALHO DE ACORDO COM A CONSTITUIÇÃO FEDERAL DE 1988}

No século XIX, (MARX, 1971) publicou uma obra que facilitou o estudo do fenômeno econômico: O Capital. Nessa obra, Marx transcende através dos estudos a questão do capital, ultrapassando os lindes meramente econômicos. Ele explica duas situações muito interessantes, conforme segue:

- $\quad$ o capital é uma relação social de produção, vivenciada historicamente, fruto de todo um processo de acumulação dos excedentes praticados pelos modos de produção antecedentes, seja pela força ideológica, pela violência ou pela apropriação monopolística;

- $\quad$ tudo se transforma em mercadoria, especialmente o trabalho humano (grifo). Para que isso ocorra, é imprescindível que uma classe se torne proprietária da tota- 
lidade dos meios de produção (burguesia), e a outra não tenha mais como produzir sua própria subsistência, senão com a venda da única "coisa" que dispõe: a força de trabalho.

A Constituição Federal do Brasil, promulgada em 05 de outubro de 1988 traz várias passagens em que há a valorização do trabalho.

$\mathrm{O}$ art. $1^{\mathrm{o}}$ da Carta Magna explana que:

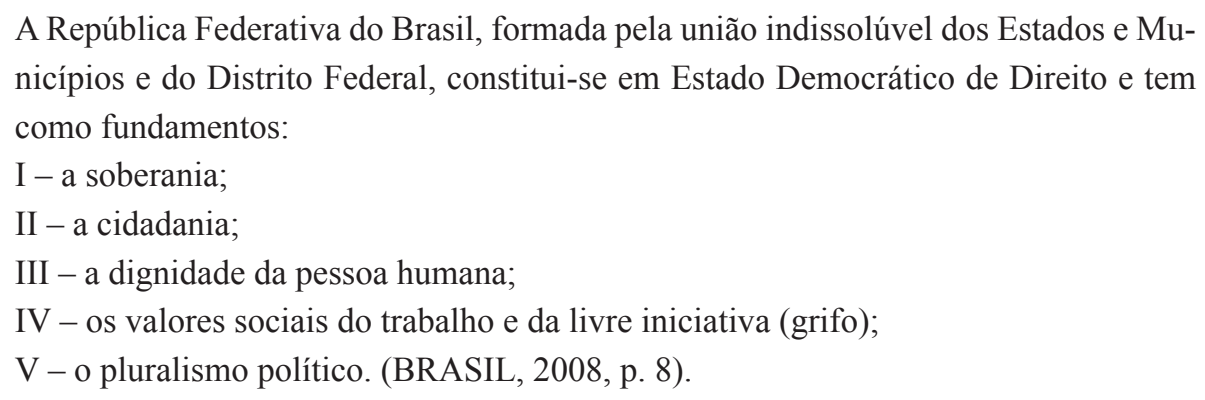

A Constituição Federal de 1988 é a primeira que integra ao elenco dos direitos fundamentais os direitos sociais, haja vista que antes eram distribuídos no capítulo pertinente à Ordem Econômica e Social. Já o art. 170 da Constituição de 1988 trata da Ordem Econômica e Financeira e apresenta os seguintes fundamentos:

\footnotetext{
Art. 170. A ordem econômica, fundada na valorização do trabalho humano e na livre iniciativa, tem por fim assegurar a todos existência digna, conforme os ditames da justiça social, observados os seguintes princípios:

$[\ldots]$

VII - busca do pleno emprego. (grifo nosso). (BRASIL, 2008, p. 51).
}

O art. 193 traz o termo "primado", com o sentido de emprestar excelência, superioridade, primazia ao trabalho, como fator de fomento ao bem-estar comunitário, senão vejamos: "art. 193. A ordem social tem como base o primado do trabalho, e como objetivo o bem-estar e a justiça sociais."

Para que haja a devida valorização do trabalho é obrigatória a leitura conjugada do caput do art. $7^{\circ}$, com seu parágrafo $1^{\circ}$, ou seja, busca-se, entre outras situações, uma relação contratual protegida contra a resilição arbitrária ou sem justa causa.

A carta de 1988 é de cunho social e repele valores decorrentes do Estado liberal, dentre vários, o culto exagerado ao individualismo. 


\section{TRABALHO ANÁLOGO AO DE ESCRAVO E O DESRESPEITO AOS DIREITOS FUNDAMENTAIS}

O início da escravidão ou trabalho compulsório perde-se no tempo. De acordo com Childe (apud OLIVIERI, 2010):

[...] em um determinado momento da pré-história, os homens perceberam que os prisioneiros de guerra - normalmente sacrificados em cultos religiosos - poderiam ser usados para o trabalho ou 'domesticados' como os animais.

Nas civilizações antigas - Egito, Babilônia, Grécia e Roma - a escravidão era uma prática recorrente. Durante a Idade Média, a partir da reestruturação da sociedade européia de acordo com a ordem feudal, a escravidão ganhou nova roupagem através da servidão, sendo uma forma "mais branda", do trabalho compulsório. (CHILDE apud OLIVIERI, 2010).

O autor Martins (1999, p. 161) é muito objetivo quando define o que é ser escravo:

Escravo é quem não é senhor de si mesmo; é um dependente de outro e também sua propriedade. Ele é uma mercadoria com qualquer outra, destituído de vontade própria, como um par de sapatos, uma camisa, um carro, um boi.

A escravidão é uma forma de trabalho forçado que implica o controle absoluto de uma pessoa por outra ou, em outras ocasiões, um grupo social por outro.

Além do art. $6^{\circ}$ da Constituição de 1988, pode-se citar também os seguintes no combate à prática do trabalho análogo à escravidão: art. $1^{\circ}$, II, III e IV; art. $3^{\circ}$, I, III e IV; art. $4^{\circ}$, II; art. $5^{\circ}$ III; art. $7^{\circ}$, XXII, XXVIII; art. 170, III; art. 186, III, IV e art. 193.

A Organização Internacional do Trabalho (2010) conceitua da seguinte forma o trabalho análogo ao de escravo:

Toda a forma de trabalho escravo é trabalho degradante, mas o recíproco nem sempre é verdadeiro. O que diferencia um conceito do outro é a liberdade. Quando falamos de trabalho escravo, falamos de um crime que cerceia a liberdade dos trabalhadores. Essa falta de liberdade se dá por meio de quatro fatores: apreensão de documentos, presença de guardas armados e "gatos" de comportamento ameaçador, por dívidas ilegalmente impostas ou pelas características geográficas do local, que impedem a fuga. 
O Direito Brasileiro não deixou de criminalizar o trabalho análogo ao de escravo, haja vista a Lei n. 10.803/2003, que trouxe alterações no art. 149 do Código Penal Brasileiro, conforme segue:

Art. 149. Reduzir alguém à condição análoga à de escravo, quer submetendo-o a trabalhos forçados ou a jornada exaustiva, quer sujeitando-o a condições degradantes de trabalho, quer restringindo, por qualquer meio, sua locomoção em razão de dívida contraída com o empregador ou preposto:

Pena - reclusão, de dois a oito anos, e multa, além da pena correspondente à violência.

$\S 1^{\circ}$ - Nas mesmas penas incorre quem:

I - cerceia o uso de qualquer meio de transporte por parte do trabalhador, com o fim de retê-lo no local de trabalho;

II - mantém vigilância ostensiva no local de trabalho ou se apodera de documentos ou objetos pessoais do trabalhador, com o fim de retê-lo no local de trabalho;

$\S 2^{\circ}$ - A pena é aumentada de metade, se o crime é cometido:

I - contra criança ou adolescente;

II - por motivo de preconceito de raça, cor, etnia, religião ou origem. (BRASIL, 1940).

É importante que o conceito de trabalho análogo ao de escravo seja bem delimitado, afastando, desse modo, a tipificação de determinadas condutas que, mesmo infringindo normas administrativas, não podem ser classificadas como o crime propriamente dito. Assim discorre o autor (LEITE, 2005, p. 145):

O fator determinante para caracterizar trabalho escravo é o cerceamento da liberdade. O trabalhador fica sem condições de sair do local onde está sendo explorado, sofrendo, a rigor, três tipos de coação:

1. coação econômica - dívida contraída com o transporte para fazenda e compra de alimento. O empregado tenta saldar a dívida, mas não consegue devido aos elevados valores cobrados;

2. coação moral/psicológica - ameaças físicas, e até de morte, por parte do responsável pela fazenda e constante presença de capataz, armado, em meio aos trabalhadores;

3. coação física - agressão aos trabalhadores como forma de intimidação.

A utilização do trabalho análogo ao de escravo ofende o interesse difuso nas relações trabalhistas, haja vista que viola o ordenamento jurídico e afronta a dignidade humana, conforme já estudado. 


\section{A OROGANIZAÇÃO INTERNACIONAL DO TRABALHO (OIT) E O COMBATE AO TRABALHO ANÁLOGO AO DE ESCRAVO}

O reconhecimento oficial do trabalho análogo ao de escravo no Brasil deu-se, efetivamente, em 1995, apesar de diversas denúncias ao Comitê da OIT. Apesar desse agravante, o Brasil foi um dos primeiros países do mundo a assumir internacionalmente a existência da escravidão contemporânea.

Há uma página na internet destinada especialmente à OIT no Brasil, o mesmo mostrase muito interessante e que reconhece os esforços do Brasil no combate a esse crime tão desumano e cruel.

Através dessa ação conjunta, o Brasil está se tornando uma referência na efetividade do combate ao trabalho forçado, ou trabalho análogo ao de escravo. Isso somente é possível combinando-se políticas públicas eficazes e a mobilização dos mais diversos setores da sociedade. Polícia Federal, Ministério do Trabalho e Emprego e Ministério Público do Trabalho estão engajados na mesma luta: proporcionar melhores condições de trabalho, assim como resgatar a dignidade de cada trabalhador, dignidade essa totalmente esquecida por muitos exploradores da mão-de-obra humana.

\section{FATORES QUE CONTRIBUEM PARA O TRABALHO ENÁLOGO AO DE ESCRAVO NO BRASIL E SUAS CONSEQUENCIAS}

O trabalho análogo ao de escravo viola os princípios mais sagrados de liberdade e dignidade da pessoa. $\mathrm{O}$ atual modelo de desenvolvimento, assim como a não promoção da reforma agrária no Brasil dificultam muito o combate ao trabalho análogo ao de escravo.

Decisões judiciais favoráveis aos empregadores que exploram o trabalho análogo ao de escravo também é um fator que contribui para a perpetuidade. Em 2006, o Supremo Tribunal Federal decidiu que a competência para julgar denúncias criminais de trabalho análogo ao de escravo é da Justiça Federal.

Já no início de 2010 foram registrados vários casos, sendo um dos mais famosos envolvendo as Lojas Marisa, conforme descreve (HASHIZUME, 2010):

O ponto de partida foi uma operação fiscal da SRTE-SP realizada no último dia 18 de fevereiro, que inspecionou todas as instalações de uma pequena oficina de costura registrada como Indústria de Comércio e Roupas CSV Ltda., em nome do boliviano 
Valboa Febrero Gusmán. No sobrado da Igreja "Boas Novas de Alegria”, localizado na Vila Nova Cachoeirinha, Zona Norte da capital paulista, a fiscalização encontrou 16 pessoas de nacionalidade boliviana (uma delas com menos de 18 anos) e um jovem peruano trabalhando em condições análogas à escravidão na fabricação de peças de vestuário feminino para a Marisa, que se apresenta como 'a maior rede de lojas femininas do país'. Foram apreendidos cadernos com anotações que remetem diretamente a cobranças ilegais de passagens da Bolívia para o Brasil, a 'taxas' não permitidas de despesas designadas com termos como 'fronteira' e 'documentos' - o que, segundo a fiscalização, consiste em 'fortes indícios de tráfico de pessoas' -, ao endividamento por meio de vales e a descontos indevidos nos salários. Há registros de 'salários' de $\mathrm{R} \$ 202$ e de $\mathrm{R} \$ 247$, menos da metade do salário mínimo ( $\mathrm{R}$ \$510) e menos de um terço do piso da categoria $(\mathrm{R} \$ 766)$.

O Ministério do Trabalho e Emprego possui a "lista suja" — cadastro de empresas que utilizam trabalho análogo ao de escravo. Particularmente no Paraná, em especial na cidade de Porecatu, ocorreram denúncias de trabalho análogo ao de escravo, apresentadas pelo Ministério do trabalho e Emprego, como sendo as mais graves encontradas nos últimos tempos no setor sucroalcooleiro, de acordo com a auditora fiscal do trabalho Jacqueline Carrijo, Coordenadora da ação que resgatou 228 trabalhadores da empresa.

O grupo móvel lavrou 153 autos de infração, interditou cinco frentes de trabalho - por ausência de sanitários, água fresca e produtos para higienização - e apreendeu 39 (do total de 43) ônibus irregulares que transportavam trabalhadores. Segundo os fiscais, enxadas, limas e outros instrumentos utilizados no trabalho eram descontados do salário dos trabalhadores. Os cortadores de cana retornavam ao alojamento mantido pela empresa - sem luz elétrica nem instalações sanitárias - depois de uma jornada excessiva de trabalho de 12 horas, sem direito a repouso. (MAIS DE 200 CORTADORES..., 2008).

Em que pese à empresa tenha sido condenada em várias obrigações, a justiça do trabalho decidiu no sentido de não se caracterizar trabalho análogo ao de escravo, conforme segue:

Pelo que se colhe dos documentos anexados à inicial, todos os 155 trabalhadores têm contratos registrados em CTPS, recebem sua remuneração na mesma data que os milhares de empregados da parte passiva, têm contas do FGTS na Caixa Econômica Federal, são cadastrados no PIS - Programa de Integração Social, suas admissões no emprego foram informadas ao Ministério do Trabalho e Emprego, através do CAGED, e pelo que se sabe, não têm sua liberdade de locomoção (direito de ir e vir) cerceada, não havendo notícia de que são obrigados/forçados a prestarem serviços aos demandados. (BRASIL, 2009b). 
Há uma ideia generalizada de que o trabalho análogo ao de escravo acontece apenas nas regiões norte e nordeste do país, por serem áreas muito distantes, o que é um equívoco. Condições degradantes estão presentes em todo país, não importando o grau de desenvolvimento econômico do Estado.

\section{MEDIDAS PROCESSUAIS CABÍVEIS E SUJEITOS COMPETENTES PARA O COM- BATE AO TRABALHO ANÁLOGO AO DE ESCRAVO}

A Ação Civil Pública é um instrumento de cidadania, com o objetivo de defender quaisquer interesses metaindividuais da sociedade.

A Constituição Federal de 1988 é muito clara quando esclarece que:

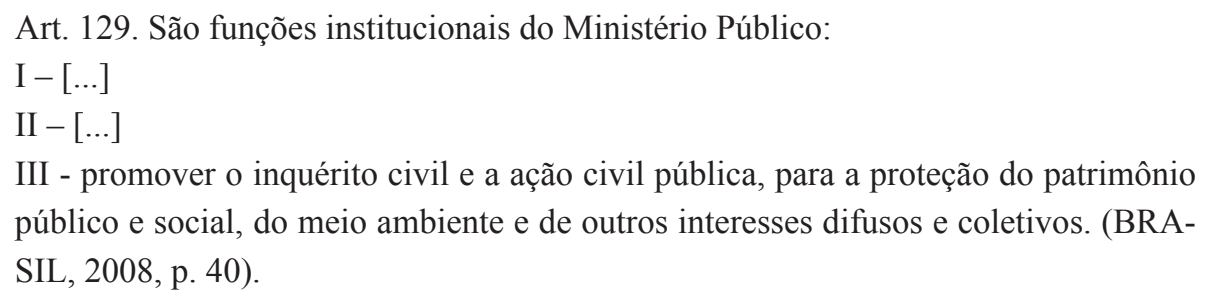

Pode o juiz, se verificado que há fumus boni iuris e periculum in mora, conceder liminar, seja prevenindo o dano, seja prevenindo sua propagação. O Ministério Público tem autorização para solicitar informações em quaisquer órgãos, certidões, exames e perícias, assim como poderá solicitar abertura de inquérito civil.

O juiz tem a faculdade de, já na inicial, quando for cumprimento de obrigação de fazer ou não fazer, determinar a cessação da atividade nociva, sob pena de cominação de multa diária (astreinte).

Já a reclamatória trabalhista é a ação judicial que visa resgatar direitos decorrentes de contrato de trabalho, expressa ou tacitamente celebrado entre duas ou mais partes, e se inicia com a formalização do processo na Justiça do Trabalho, movido pelo trabalhador contra a empresa ou equiparada a empresa ou empregador doméstico a quem haja prestado serviços.

Uma terceira opção é a criminalização do trabalho escravo. Uma das formas para reprimir a exploração do trabalho forçado foi a tipificação penal da conduta no art. 149 do CP, já citada anteriormente. 
Art. 149. "Reduzir alguém a condição análoga à de escravo: pena - reclusão, de 2 (dois) a 8 (oito) anos".

A partir de 2003 houve alteração, a partir da Lei n. 10.803, e o artigo se tornou mais minucioso, ou seja, é crime reduzir alguém à condição análoga a de escravo, não apenas sujeitando-a a trabalhos forçados ou jornadas exaustivas, mas também às condições degradantes, restringindo sua locomoção em razão de dívida contraída com o empregador ou preposto.

Constata-se que há alguns artigos no Código Penal que trabalham a questão do combate ao trabalho análogo ao de escravo, basta aplicá-los à realidade brasileira. Falta vontade política para pôr em prática as sanções.

\section{SUJEITOS RESPONSÁVEIS PELO COMBATE AO TRABALHO ANÁLOGO AO DE ESCRAVO}

Com relação aos direitos metaindividuais, o art. $8^{\circ}$, inciso III da Constituição Federal prevê que os sindicatos também têm legitimidade para ingressar com ação civil pública. Os sindicatos têm a faculdade de ingressar com ação civil pública em face do empregador-escravizador, tendo como objetivo cessar as práticas escravizantes em determinada localidade, assim como atos de aliciamento, levando a denúncia ao Ministério Público Federal para as devidas providências quanto à responsabilização criminal.

O Ministério Público da União, em particular o do Trabalho, teve sua atuação ampliada a partir da Constituição Federal de 1988. Inicialmente era um órgão vinculado ao Poder Executivo e atualmente é um autêntico defensor dos interesses da sociedade, sejam eles sociais ou individuais indisponíveis, como preconiza o art. 127, caput, da CF/88.

A partir da Lei Complementar n. 75/93, compete ao Ministério Público do Trabalho promover a ação civil pública no âmbito da Justiça do Trabalho para a defesa de interesses coletivos, assim como o art. 83, I, disciplina que é prerrogativa do MPT promover as ações que lhes sejam atribuídas pela CF e pelas leis trabalhistas. Constata-se, a partir disso, que a ação civil pública, desde que se trate de tutela de interesses difusos, coletivos ou individuais homogêneos, pode ser um instrumento extremamente eficaz.

Já o Ministério do Trabalho e Emprego - MTE, iniciou suas atividades, originariamente, em 1930, com a denominação Ministério do Trabalho, por meio do Decreto n. 19.433, de 26 de novembro, assinada pelo Presidente Getúlio Vargas. Houve várias alterações em sua estrutura e, em 1999, o Ministério passou a se denominar Ministério do Trabalho e Emprego, por meio da Medida Provisória $n^{\circ} 1.799$, de $1^{\circ}$ de janeiro. 
No site do MTE está disponibilizado um Cadastro de Empregadores que exploram o trabalho análogo, previsto na Portaria n. 540/2004, com atualização semestral. Para que o nome do empregador seja retirado do Cadastro (exige-se dois anos), há uma verificação no sentido de confirmar que as irregularidades foram sanadas.

As principais causas de manutenção do nome no Cadastro são: não quitação das multas impostas, reincidência na prática do ilícito e, em razão dos efeitos de ações em trâmite no Poder Judiciário.

\section{AÇÕES DE COMBATE AO TRABALHO ANÁlOGO AO DE ESCRAVO NO BRASIL}

A Proposta de Emenda Constitucional (PEC) teve seu início em 2001. Foi votada no Senado duas vezes e aprovada. Já na Câmara dos Deputados foi votada e aprovada apenas uma vez. A votação em primeiro turno foi realizada em agosto de 2004, ainda sob o efeito do clamor nacional resultante da Chacina de Unaí, episódio em que três auditores fiscais do trabalho e um motorista foram assassinados enquanto faziam inspeções em Minas Gerais. Ainda resta a segunda votação e aprovação. Atualmente tal proposta encontra-se engavetada.

Estabelecer a pena de perdimento da gleba onde for constada a exploração de trabalho escravo (expropriação de terras), revertendo a área ao assentamento dos colonos que já trabalhavam na respectiva gleba. Altera a Constituição Federal de 1988. (BRASIL, 2009a).

A Proposta de Emenda Constitucional (PEC) 438/2001, que prevê a expropriação de terra em que ficar comprovada a exploração de trabalho escravo e tem apoio de um abaixo-assinado com mais de 168 mil adesões, se tornou quase um sinônimo do combate à escravidão contemporânea. À espera de votação no Plenário da Câmara dos Deputados há quase seis anos (após aprovação em primeiro turno em agosto de 2004), a PEC do Trabalho escravo corre sério risco de 'perecer' engavetada por mais uma legislatura caso não seja 'ressuscitada' pela lideranças da Casa até 5 de abril, quando se encerra o prazo acordado até aqui para a escolha (ou descarte completo) de emendas que ainda poderão ser apreciadas em 2010. (ROCHA; HASHIZUME, 2010).

Percebe-se a prevalência do interesse político em detrimento do interesse social. Não há que se admitir que uma PEC dessa importância para o desenvolvimento de um país não seja votada e aprovada em virtude de uma Copa do Mundo de futebol. É inadmissível e tal posicionamento subestima os brasileiros. 
Caso seja aprovada em segundo turno pela Câmara, a emenda poderá retornar ao Senado em virtude de modificações promovidas pelos deputados.

\section{POLÍTICAS DE COMBATE AO TRABALHO ANÁlOGO AO DE ESCRAVO}

O Plano Nacional pela Erradicação do Trabalho Escravo foi elaborado pela Comissão Especial do Conselho de Defesa dos Direitos da Pessoa Humana (CDDPH), constituída pela Resolução 05/2002 do CDDPH. Reúne entidades e autoridades nacionais ligadas ao tema. O referido Plano atende às determinações do Plano Nacional de Direitos Humanos e expressa uma política pública permanente que deverá ser fiscalizada por um órgão ou fórum nacional dedicado à repressão do trabalho escravo.

As principais ações contemplam a prevenção, reinserção dos trabalhadores e repressão econômica, pontos que precisam ser mais bem explorados para que o objetivo seja atingido.

Já o Pacto Nacional pela Erradicação do Trabalho Escravo no Brasil é uma iniciativa do Observatório Social-OS, OIT (Organização Internacional do Trabalho, órgão da ONU), Instituto Ethos e pela ONG e agência de notícias Repórter Brasil. Com a ajuda dos órgãos fiscalizadores estatais - imprescindíveis para a localização e punição de quem utiliza mão-deobra escrava - o Pacto, em vigor desde maio de 2005, tem atualmente a adesão de empresas que representam mais de $25 \%$ do PIB nacional.

O Instituto Observatório Social (IOS) tem por objetivo monitorar e gerar relatórios sobre as ações empreendidas pelos signatários voltadas para a erradicação do trabalho análogo ao de escravo no Brasil e provocar intercâmbio dessas informações entre as empresas e sindicatos envolvidos.

O trabalho análogo ao de escravo é, na maioria das vezes, um crime silencioso, ou seja, ele é perpetrado com a colaboração do próprio poder público, na medida em que se omite na implementação de políticas de prevenção e repressão.

Apenas a desapropriação de áreas com incidência de trabalho análogo ao de escravo não trará melhores condições de vida aos trabalhadores. É premente a necessidade de valorização do trabalho no campo, em especial, assim como efetiva implementação dos direitos e garantias fundamentais preconizadas na Constituição Federal de 1988.

A implantação da reforma agrária é tão urgente quanto necessária. Trabalhadores e empresários precisam, conjuntamente, ser respeitados em suas individualidades e isso somente será alcançado após a tão almejada “justiça social”, e justiça social só se realiza com vontade 
política, aliada às políticas públicas de combate ao trabalho degradante. A reforma agrária é base indispensável para a construção de um outro modelo de desenvolvimento no campo, includente e sustentável.

Seria importante a concessão do "Programa Bolsa Família" para trabalhadores oriundos da exploração do trabalho análogo ao de escravo, não podendo, contudo, tornar-se permanente, haja vista que programas sociais devem ter um período determinado para findar, caso contrário, torna-se um programa assistencialista. O Bolsa Família deve ser apenas um incentivo para a futura qualificação profissional e reinserção no mercado de trabalho.

A atualização da "Lista Suja", elaborada pelo Ministério do Trabalho e Emprego é uma ótima ferramenta para a denúncia de casos de exploração do trabalho análogo ao de escravo. Tal ferramenta não deve permitir omissões e/ou injustiças. A divulgação da "lista suja" é importante no sentido que informa os verdadeiros exploradores, sejam eles grandes ou pequenos empregadores. A atualização deve ser amplamente divulgada no meio jornalístico para dar visibilidade aos crimes cometidos.

Vários órgãos devem trabalhar conjuntamente para erradicar a exploração do trabalho análogo ao de escravo, quais sejam: a) INCRA; b) PF; c) PRF, d) MTE; e) MP. O trabalho isolado de apenas uma Instituição e/ou Entidade não proporciona bons resultados ou apresenta resultados pontuais.

A denúncia anônima, que pode e deve ser feita por qualquer cidadão tem se mostrado como uma das opções mais utilizadas, ela traz bons resultados se aliada ao efetivo combate no sentido de respostas rápidas e eficientes por parte do poder público. Uma denúncia anônima pode resgatar dezenas de famílias da extrema pobreza e da falta de dignidade.

O Estado tem condições de aumentar o grau de participação da sociedade mediante mecanismos de cidadania e o trabalhador precisa se conscientizar que ele é importante para o desenvolvimento do país.

Um dos objetivos estratégicos é combater e prevenir o trabalho análogo ao de escravo, tendo como ações programáticas promover a efetivação do Plano Nacional para Erradicação do Trabalho Escravo, assim como destinar recursos do FAT - Fundo de Amparo ao Trabalhador para capacitação técnica e profissionalizante, tanto de trabalhadores rurais, quanto de povos e comunidades tradicionais, como medida preventiva ao trabalho análogo ao de escravo, assim como implementar políticas de reinserção social dos trabalhadores libertados. 
Para Gláucio Araújo, Procurador do Trabalho, a sociedade organizada (sindicatos, governo, mídia etc) tem o dever de promover eventos regionais de conscientização ao produtor rural, considerando que o trabalho análogo ao de escravo está concentrado nesta área e muitos desconhecem a sua definição ou caracterização. O ideal não é a mera fiscalização com imposição de multas, mas sim uma atuação preventiva. (GONÇALVES, 2009).

No dia 13 de março de 2010 houve a criação da Frente Parlamentar Mista pela Erradicação do Trabalho Escravo, num primeiro momento os esforços do grupo serão voltados para a aprovação da proposta de emenda à Constituição (PEC 438/01), do ex-senador paraense Ademir Andrade, que trata da expropriação e do confisco de terras ou de propriedades onde a prática do trabalho análogo ao de escravo for constatada e comprovada.

A atuação efetiva do Poder Legislativo é imprescindível para impor medidas efetivas de proteção ao trabalhador, no entanto, o que tem predominado é a total inércia das duas Casas Legislativas.

É imperiosa a necessidade de gerar alternativas de emprego e renda para as vítimas de trabalho análogo ao de escravo, assim como criação de linhas de financiamento para trabalhadores resgatados, com o objetivo de apoiá-los no processo de rompimento do ciclo que leva à “escravidão".

Os recursos do FAT - Fundo de Amparo ao Trabalhador devem ser investidos em programas que combatam o trabalho análogo. Cada cidadão pode contribuir e a sociedade, como um todo, deve cobrar trabalho efetivo das autoridades públicas, seja fiscalizando e principalmente denunciando o trabalho análogo ao de escravo, um crime que não pode existir em uma sociedade democrática.

É muito importante a sociedade ter conhecimento para onde o dinheiro público, em especial, está sendo investido. A partir desse conhecimento torna-se mais fácil fiscalizar.

\section{CONCLUSÃO}

A Constituição Federal de 1988 possui como eixo norteador a dignidade da pessoa humana. Para tanto, a valorização do trabalho humano é um dos requisitos a ser cumprido com a finalidade de alcançar o referido objetivo.

O ser humano deve ser protegido, valorizado, por se tratar do fim perseguido constitucionalmente. Por esta razão, todas as ações que acabam contrariando a busca daquele objetivo 
são repelidas pela ordem constitucional. Dentro desta interpretação sistêmica que se faz da Constituição Federal, o trabalho análogo ao de escravo deve ser repelido, por representar a antítese de um modelo valorativo adotado pelo texto constitucional.

Verificou-se que, apesar de ser um dos princípios constitucionais e ao mesmo tempo um dos objetivos a serem alcançados, a liberdade no trabalho com dignidade ainda não é estendida a todos os cidadãos no Brasil. Problema atual e grave é o trabalho análogo ao de escravo, um assunto, às vezes, tão distante e tão próximo da realidade.

O trabalho análogo ao de escravo no Brasil pode ser explicado historicamente enquanto uma formação que decorreu do antigo sistema escravocrata, e que não foi superado, ainda que implantado o trabalho assalariado.

As estatísticas demonstram que o trabalho análogo ao de escravo não está mais restrito às regiões Norte e Nordeste, mas sim espalhado por todo território, por exemplo, em Goiás e Mato Grosso do Sul. Isso se deve porque, dentre outros fatores, a fiscalização está mais rigorosa.

A escravidão contemporânea é sustentada por um tripé: impunidade, ganância e pobreza. Faz-se necessário, não apenas combater esse crime, mas também rever nosso sistema de Justiça, padrões de consumo e modelo de desenvolvimento.

Nem todo trabalho degradante é trabalho análogo ao de escravo, mas o contrário sempre é verdadeiro. Para se caracterizar o trabalho análogo, buscou-se os mais variados conceitos, de diversos autores e entidades que possuem como objetivo combater referida forma de degradação humana. Situações como se alimentar de comida estragada, brigar com o gado pelo acesso à água são, no mínimo, situações que subestimam o trabalhador e o reduzem a uma mercadoria.

Muitas entidades e organizações trabalham conjuntamente para pôr fim a essa prática criminosa: Ministério Público do Trabalho, Polícia Federal, Ministério do Trabalho e Emprego; Organizações Não Governamentais, entre outras.

A Organização Internacional do Trabalho (OIT) criada em 1919, após o fim da primeira guerra mundial, tem um papel de destaque no cenário brasileiro e reconhecido por suas intervenções efetivas, sejam preventivas, sejam repressivas. Ações conjuntas no Brasil, envolvendo a OIT e várias Entidades e Organizações foram determinantes no enfrentamento do trabalho análogo ao de escravo. 
Existem políticas públicas de combate ao trabalho escravo, no entanto, a impunidade ainda é realidade. Confiança na impunidade, apesar de ser um crime, multas irrisórias e falta de estrutura necessária para a fiscalização, tanto de funcionários, quanto de recursos, baixo nível educacional, são alguns dos principais fatores que contribuem para a continuidade da prática criminosa.

Políticas importantes foram implementadas com o objetivo de tentar erradicar o trabalho análogo ao de escravo, tais como: Plano Nacional para a Erradicação do Trabalho Escravo e o Pacto Nacional pela Erradicação do Trabalho Escravo. Tais políticas se mostram até certo ponto, eficazes. No entanto, por ser o Brasil um país continental, constatou-se que elas necessitam ser aperfeiçoadas e desenvolvidas de forma integrativa.

Tanto o Ministério Público do Trabalho quanto o Ministério do Trabalho e Emprego são órgãos imprescindíveis do Governo Federal no sentido de aplicar punições mais severas. No entanto, as ações de estado não são suficientes para atender as necessidades encontradas. Requer-se também a participação da sociedade, principalmente através de entidades não governamentais organizadas e órgãos sindicais.

Não é admissível aguardar apenas a aprovação da PEC n. 438/2001 e pensar que todo o problema da exploração do trabalho humano será resolvido.

Instrumentos processuais mais ágeis poderão proporcionar o efetivo acesso à justiça e darão resultados mais positivos. No presente trabalho, abordou-se apenas três: Ação Civil Pública, Reclamatória Trabalhista e Criminalização do Trabalho Análogo ao de Escravo. No entanto, o que se espera no conjunto são posicionamentos concretos e rápidos por parte do Poder Judiciário.

Não somente os danos individuais dos sujeitos que sofrem o trabalho análogo devam ser devidamente indenizados, mas também deve haver a reparabilidade pelo dano social causado, com o intuito de resgatar valores sociais, éticos, haja vista que com referidas práticas degradantes do trabalho humano toda sociedade acaba sendo prejudicada, por conta que a proteção à dignidade no trabalho também se caracteriza como um interesse difuso.

Também, as indenizações a serem pagas pelos responsáveis por tais práticas deploráveis devem não somente ter a finalidade reparatória indenizatória, mas que desestimule referida prática, ou seja, que tenha o caráter também disciplinar, o que implica na dosimetria da pena de acordo com o porte econômico do causador do dano. 
Apesar do grande número de trabalhadores que ainda é submetido à situação análoga a de escravo no Brasil, registra-se avanços nos últimos anos no combate a esse tipo de crime. Antes o Brasil era denunciado pela omissão, hoje o país é referência no que se refere à criação de institutos de proteção ao trabalho humano, apesar de haver um longo caminho a percorrer para que se obtenha de forma efetiva o combate rápido e efetivo do trabalho análogo ao de escravo no Brasil.

\section{REFERÊNCIAS}

BARBOSA, Gustavo Henrique Cisneiros. A Encíclica Rerum Novarum e o direito do trabalho. Disponível em: <http:/jus2.uol.com.br/doutrina/imprimir.asp?id=3188>. Acesso em: 12 mar. 2010.

BRASIL. Constituição (1988). Constituição da República Federativa do Brasil. Brasília: Senado Federal, 2008.

BRASIL. Decreto-Lei n. 2.848, de 07 de dezembro de 1940. Código Penal. 1940. Disponível em: <http://www.planalto.gov.br/CCIVIL/Decreto-Lei/Del2848compilado.htm>. Acesso em: 27 jan. 2010a.

BRASIL. Câmara dos Deputados. Projetos de lei e outras proposições. Disponível em: $<$ http:/ www2.camara.gov.br/proposicoes/loadFrame.html?link=http://www.camara.gov.br/internet/ sileg/prop_lista.asp? $\mathrm{fMode}=1 \&$ btnPesquisar $=\mathrm{OK} \& \mathrm{Ano}=2001 \&$ Numero $=438 \&$ sigla $=\mathrm{PEC}>$. Acesso em: 21 out. 2009a.

BRASIL. Ministério do Trabalho e Emprego. A história do MTE. 2008. Disponível em: <http:/ www.mte.gov.br/institucional/historia.asp>. Acesso em: 22 maio 2010.

BRASIL. Plano Nacional para Erradicação do Trabalho Escravo. 2003. Disponível em: <http:/ www.mte.gov.br/trab_escravo/erradicacao_trab_escravo.asp >. Acesso em: 21 maio 2010.

BRASIL. Tribunal Regional do Trabalho, 9. Região. Ação Civil Coletiva $n^{\circ}$ ACPU-010182008-562-09-00-2 e Ação Declaratória de Atos nº AD-01043-2008-562-09-00-6. Porecatu, 3 jul. 2009b. Disponível em: <http:/www.trt9.jus.br/internet_base/publicacaoman.do?evento= E ditar\&chPlc $=3378994 \&$ procR $=$ AAAbqKAAZAAKbtsAAR $\&$ ctl $=1018>$. Acesso em: 23 maio 2010 .

BRESCIANI, Maria Stella Martins. Londres e Paris no século XIX: o espetáculo da pobreza. 4. ed. São Paulo: Brasiliense, 1987.

FUNDAÇÃO INSTITUTO DE DIREITOS HUMANOS. Convenção americana de direitos humanos: pacto de San José. 1969. Disponível em: <http://www2.idh.org.br/casdh.htm>. Acesso em: 3 nov. 2009. 
GOMES, Dinaura Godinho Pimentel. Direito do trabalho e dignidade da pessoa humana, no contexto da globalização econômica: problemas e perspectivas. São Paulo: LTr, 2005.

GONÇALVES, Érika. Escravidão é problema contemporâneo. Folha de Londrina, Londrina, 21 nov. 2009. Folha Opinião, p. 3.

HASHIZUME, Maurício. Escravidão de imigrantes é flagrada em oficina ligada à Marisa. Disponível em: <http:/www.brasildefato.com.br/v01/agencia//nacional/escravidão-de-imigrantese-flagrada-em-oficina-ligada-as-lojas-marisa/view>. Acesso em: 23 mar. 2010.

KANT, Immanuel. Textos selecionados: fundamentação da metafísica dos costumes. São Paulo: Abril Cultural, 1980. (Os Pensadores).

LEÃO XIII. Carta Encíclica "Rerum Novarum” sobre a condição dos operários. Disponível em: <http:/www.vatican.va/.../hf_l-xiii_enc_15051891_rerum-novarum_po.html >. Acesso em: 4 jan. 2010.

LEITE, Carlos Henrique Bezerra. A ação civil pública e a tutela dos interesses individuais homogêneos dos trabalhadores em condições análogas à de escravo. Revista do Tribunal Superior do Trabalho, Brasília, v. 71, n. 2, p. 146-173, maio/ago. 2005.

MAIS DE 200 CORTADORES são resgatados em usina de Porecatu. 2008. Disponível em: $<$ http:/www.reporterbrasil.org.br/imprimir.php?id=1407\&escravo=1>. Acesso em: 30 mar. 2010.

MARTINS, José de Souza. A escravidão nos dias de hoje e as ciladas da interpretação. In: MOREYRA, Sérgio Paulo (Org.). Trabalho escravo no Brasil contemporâneo. São Paulo: Loyola, 1999. p. 127-164.

MARX, Karl. O capital. Rio de Janeiro: Civilização Brasileira, 1971. v. 1.

Manifesto do partido comunista. São Paulo: Cortez, 1998.

OLIVIERI, Antonio Carlos. Trabalho compulsório ainda existe no Brasil. Disponível em: $<$ http://educacao.uol.com.br/historia-brasil/ult1702u64.jhtm?action=print $>$. Acesso em: 27 jan. 2010 .

ORGANIZAÇÃO DAS NAÇÕES UNIDAS NO BRASIL. Declaração dos direitos humanos. Disponível em: $<$ http:/www.onu-brasil.org.br/documentos_direitoshumanos.php $>$. Acesso em: 12 jan. 2010.

ORGANIZAÇÃO INTERNACIONAL DO TRABALHO. Erradicação do trabalho forçado. Disponível em: <http:/www.oit.org.br/prgatv/in_focus/trab_esc.php>. Acesso em: 1 fev. 2010. 
PACTO internacional sobre os direitos civis e políticos: preâmbulo. Disponível em $<$ http:// www.dhnet.org.br/direitos/sip/onu/doc/pacto2.htm>. Acesso em: 3 nov. 2009.

OCHA, Rodrigo; HASHIZUME, Maurício. PEC do trabalho escravo pode continuar "esquecida" na Câmara. 2010. Disponível em: <http:/www.reporterbrasil.com.br/ imprimir. php?id=1716\&escravo=1>. Acesso em: 23 mar. 2010.

RECEBIDO: $02 / 11 / 2010$

ANÁLOGO: 24/11/2010 